\title{
PENDAMPINGAN KELOMPOK USAHA SAMILER DI DESA PURWOASRI KECAMATAN SINGOSARI KABUPATEN MALANG UNTUK MENINGKATKAN MUTU KEMASAN DAN PEMASARAN
}

\author{
Tri Asih Wahyu $\mathbf{H}^{\mathbf{1}}$, Purwaning Budi Lestari ${ }^{\mathbf{2}}$ \\ ${ }^{1,2)}$ IKIP Budi Utomo, Malang, Jawa Timur, Indonesia \\ 1*Email: triasihibu@gmail.com \\ ${ }^{2}$ Email: purwaningbudilestari@gmail.com
}

\begin{abstract}
Mrs. Artiyam, Mrs. Suparmi, and Srikandi Women's Cooperative are partners involved in Community Partnership Program activities living in Purwoasri Village, Singosari Sub-district, Malang Regency. Mrs. Artiyam and Mrs. Suparmi are small-scale household entrepreneurs / crackers. Mrs. Artiyam and Mrs. Suparmi and Srikandi Women's Cooperative sell samiler crackers produced by Mrs. Artiyam and Mrs. Suparmi. Women's Cooperative Srikandi sell crude samiler crackers and there is no packing, so far only limited to crackle bags so it is less attractive, besides there is no online marketing because they do not have the skills to utilize IT. The solution to this problem is the training of packaging design to create an attractive packaging design and increase the selling value; training Use of IT for online marketing. With the presence of training and assistance, partner skills on packaging of products and marketing increase and increase turnover.
\end{abstract}

Keyword: samiler, packaging, marketing

\section{PENDAHULUAN}

Desa Purwoasri terletak kurang lebih 3 $\mathrm{km}$ dari jalan raya Surabaya-Malang dan berbatasan dengan desa Banjar Arum, Tunjung Tirto, Klampok dan Langlang. Masyarakat Desa Purwoasri sebagian besar bermata pencaharian sebagai buruh tani, buruh pabrik, pekerja bangunan, wirausaha skala rumah tangga/ mikro dan buruh di ladang. Ladang yang dikerjakan oleh masyarakat Desa Purwoasri banyak ditanami cabe rawit dan singkong. Singkong merupakan salah satu bahan pangan yang terkenal di Indonesia, dan bahan makanan ini juga tumbuh dengan subur di Desa Purwoasri Kecamatan Singosari Kabupaten Malang.

Banyak masyarakat

yang memanfaatkan bahan pangan ini, seperti mengolah singkong menjadi berbagai macam makanan. Salah satu contoh makanan tradisional dari hasil olahan singkong ini adalah "samiler". Samiler berbentuk seperti kerupuk dan cara membuatnya pun cukup mudah. Meskipun krupuk samiler ini tidak menggunakan bahan pengawet, krupuk ini mampu bertahan hingga satu bulan namun dalam keadaan tertutup. Bu Artiyam dan $\mathrm{Bu}$ Suparmi adalah wirausahawati samiler di Desa Purwoasri. Bu Artiyam dan Bu Suparmi menggeluti usaha ini karena melihat adanya bahan baku yang tersedia di Desa Purwoasri, selain itu proses pembuatan cukup mudah dan tidak menggunakan bahan pengawet sehingga aman dan sehat untuk dikonsumsi.

Dalam satu kali produksi Bu Artiyam dan $\mathrm{Bu}$ Suparmi mampu menghasilkan kurang lebih $10 \mathrm{~kg}$ samiler kering siap goreng dan dijual dengan harga Rp. 13.000,-/ kg. Samiler yang sudah diproduksi ini langsung diambil oleh tengkulak, bahkan tengkulak sering meminta jumlah yang lebih dari $10 \mathrm{~kg}$ tetapi karena kurangnya tenaga kerja dan proses produksi yang masih sangat sederhana maka permintaan tersebut tidak dapat terpenuhi. 
$\mathrm{Bu}$ Artiyam dan $\mathrm{Bu}$ Suparmi menjalankan usaha yang masih sangat sederhana. Belum ada teknik pengemasan dan pemasaran. Selama ini samiler yang sudah kering dijual di toko-toko sekitar Desa Purwoasri. Pengembangan usaha juga belum dilakukan sehingga produk yang dijual berupa kerupuk samiler mentah. Belum ada pengemasan yang bagus dan menarik selama ini karena pengemasan hanya dilakukan dengan kantung kresek.

Mitra ketiga yaitu Koperasi Wanita Srikandi. Koperasi wanita Srikandi didirikan pada tahun 2010 dengan pengurus inti terdiri dari Ketua sami Yatmah, Sekretaris:, Lulik M. Z. dan Bendahara: Ana setyowati. Koperasi Wanita Srikandi adalah koperasi simpan pinjam yang terdiri atas 75 anggota. Saat ini Koperasi Wanita belum memiliki investasi untuk keberlanjutan dan kemandirian dalam bentuk usaha. Koperasi Wanita Srikandi juga menjual kerupuk samiler yang diproduksi oleh $\mathrm{Bu}$ Suparmi dan $\mathrm{Bu}$ Artiyam namun dijual dalam bentuk kerupuk mentah dan dalam kontong kresek saja.

\section{METODE PELAKSANAAN}

Metode Pelaksanaan dalam kegiatan pengabdian ini adalah melakukan survey untuk mengetahui permasalahan utama yang harus dicarikan solusinya dan berdasarkan pada kesepakatan mitra. Metode yang digunakan adalah dengan melakukan pelatihan dan pendampingan dalam aspek pengemasan dan pemasaran berbasis Informasi dan Teknologi (IT). Pelatihan pemasaran dilakukan selama dua hari yakni
10-11 Maret 2018 sedangkan pelatihan pemasaran dilakukan pada tanggal 28-29 April 2018.

Pelaksanaan pelatihan dilakukan dengan cara memberikan materi yang relevan dan sesuai perkembangan jaman serta memberikan keterampilan kepada mitra dengan mengajarkan dan mendampingi mitra untuk membuat kemasan yang menarik dan membuat desain pemasaran online melalui whatsapp, facebook, instagram, dan google bussines. Pelaksana pelatihan adalah tim pelaksana $\mathrm{PkM}$ dan dibantu oleh mahasiswa IKIP Budi Utomo yang sedang memprogram matakuliah Pemberdayaan Masyarakat Berbasis Potensi (PMBP).

\section{HASIL DAN PEMBAHASAN}

\section{A. Hasil Pengabdian Kepada Masyarakat}

Pelaksanaan pelatihan pengemasan dan pemasaran berdampak pada:

1. Meningkatkanya wawasan dan pemahaman mitra tentang pengemasan dan pemasaran produk kerupuk samiler.

2. Meningkatnya keterampilan mitra dalam pemanfaatan media pemasaran online.

3. Meningkatnya nilai jula produk karena adanya pengemasan yang lebih baik

4. Meningkatnya omset karena ada pemasaran online yang memiliki jangkauan lebih luas.

Berikut ini adalah tabel yang menunjukkan adanya peningkatan tingkat pemahaman mitra setelah memperoleh pelatihan pengemasan dan pemasaran.

Tabel 1. Tingkat Pemahaman Mitra Peserta Pelatihan

\begin{tabular}{lcc}
\hline \multirow{2}{*}{ Materi } & \multicolumn{2}{c}{ Prosentase pemahaman } \\
\cline { 2 - 3 } & Sebelum pelatihan & Setelah pelatihan \\
1 (Pemasaran) & $20 \%$ & $80 \%$ \\
2 (Pengemasan) & $30 \%$ & $90 \%$ \\
\hline
\end{tabular}

Berdasarkan Tabel 1 di atas dapat diketahui bahwa mitra peserta pelatihan memahami materi pelatihan dan mendapatkan wawasan baru yang lebih luas sehingga dapat digunakan modal dalam pengembangan usaha lebih inovati lagi ke depannya. 
Masing masing pelatihan dilakukan selama dua hari, hari pertama penyampaian materi yang dibantu oleh mahasiswa dan pada hari kedua praktek membuat desain kemasan dan pemasaran online. Berikut ini adalah foto pelatihan pengemasan dan pemasaran serta hasil desain kemasan dan media pemasaran yang digunakan. Foto pelatihan pemasaran dan pengemasan produk dapat dilihat pada Gambar 1. Kemasan produk dapat dilihat pada Gambar 2. Media pemasaran online dapat dilihat pada Gambar 3.
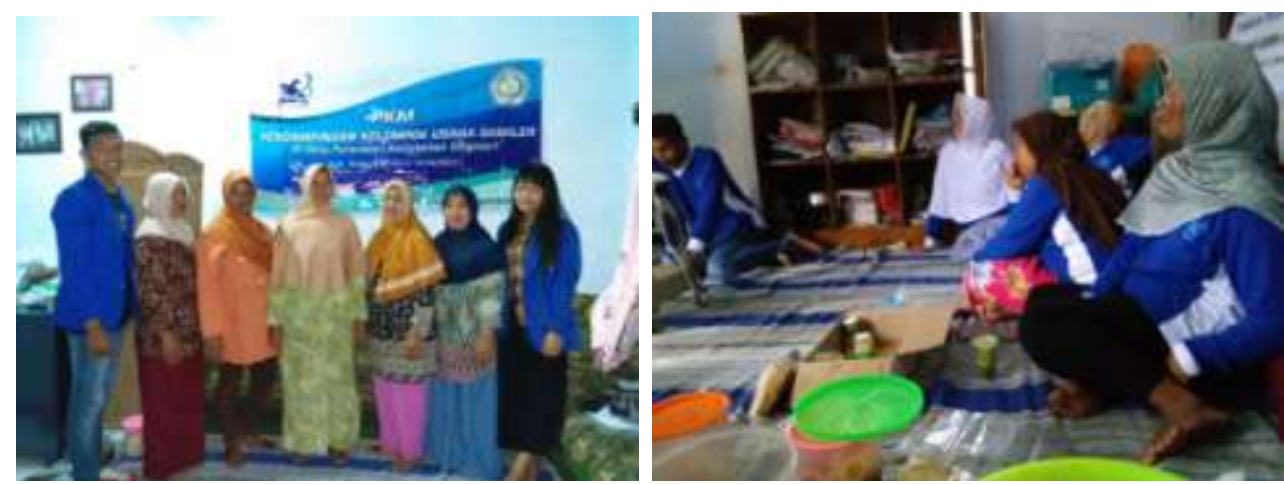

Gambar 1. Foto Pelatihan Pemasaran dan Pengemasan (Sumber: doc. Pribadi, 2018)

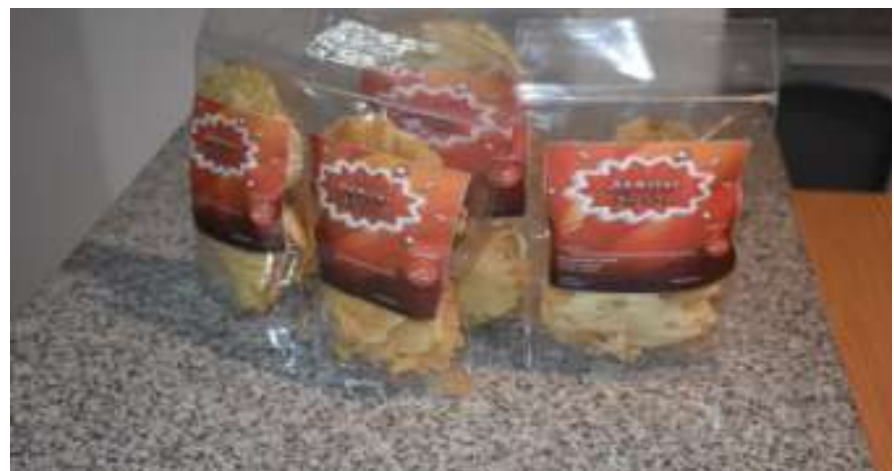

Gambar 2. Kemasan Produk (Sumber: doc. Pribadi, 2018)

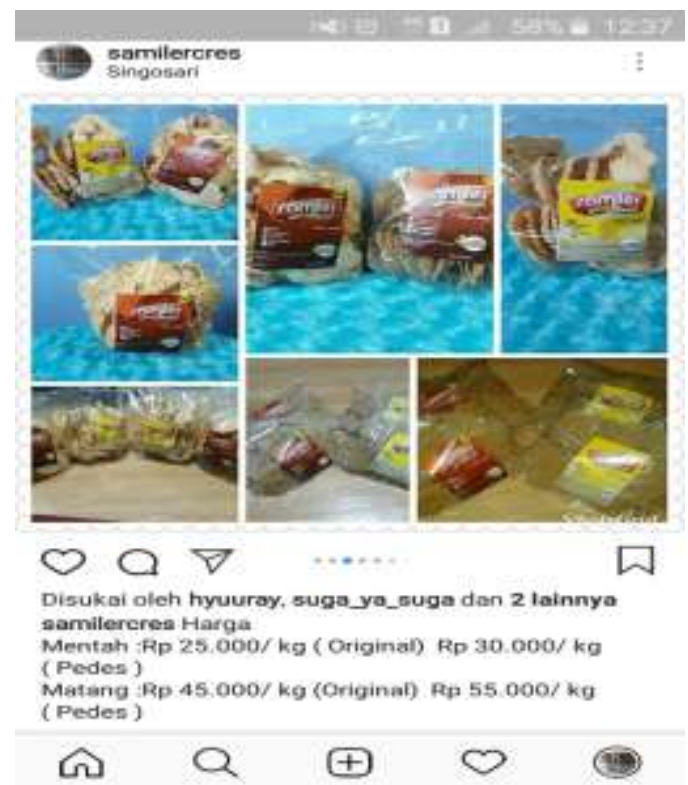

Gambar 3. Media Pemasaran Online (Sumber: doc. Pribadi, 2018) 


\section{B. Pembahasan}

Pengemasan dan pemasaran adalah faktor penting yang dapat menentukan keberhasilan usaha. Dengan adanya pengemasan yang bagus dan menarik dapat meningkatkan nilai jual produk sehingga omset juga akan meningkat. Daya tarik suatu produk tidak dapat terlepas dari kemasannya. Kemasan merupakan "pemicu" karena ia langsung berhadapan dengan konsumen. Karena itu kemasan harus dapat mempengaruhi konsumen untuk memberikan respon positif, dalam hal ini membeli produk; karena tujuan akhir dari pengemasan adalah untuk menciptakan penjualan (Iwan dalam Cenadi, 2000).Adanya kemasan dalam suatu produk akan memberikan keuntungan bagi produsen maupun konsumen. Hal ini sesuai pernyataan Alma dalam Syamsudin (2015) yaitu bagi produsen, kemasan memberikan keuntungan dalam hal:

1. Melindungi barang-barang yang dibungkusnya sewaktu barang-barang tersebut bergerak melalui proses marketing.

2. Memudahkan pedagang eceran untuk membagi-bagi atau memisahkan barang tersebut.

3. Untuk mempertinggi nilai isinya dengan daya tarik yang ditimbulkan oleh pembungkus, sehingga menimbulkan ciri-ciri khas produk tersebut.

4. Untuk identitas, mudah dikenal, karena adanya label atau merek yang tertera pada pembungkus.

5. Pembungkus dapat digunakan sebagai alat komunikasi karena membawa berita atau catatan mengenai produk itu.

6. Pembungkus sebagai salesmen diam, seperti supermarket. Disini para pembeli tidak dilayani oleh salesmen tetapi pembeli cukup mengetahui dan memilih barangnya sendiri dengan membaca label pada pembungkus.

7. Selain packaging yang baik, perusahaan juga harus membuat kemasan yang indah untuk menarik konsumen.

Sedangkan keuntungan dari kemasan bagi konsumen antara lain:
1. Dengan adanya pembungkus produk akan tetap bersih dan praktis untuk dibawa kemana saja, tahan lama, dan mudah disimpan.

2. Dengan pembungkus berarti timbangan di dalamnya benar.

3. Pengemasan menunjukan kualitas barang seperti menerangkan isi yang dibungkus.

4. Dengan adanya pembungkus, pembeli dapat membeli dengan jumlah yang cukup (diperlukan).

5. Sering pembungkus yang isinya telah habis terpakai masih dapat digunakan untuk tempat penyimpan barang lain.

6. Pembungkus yang memberi informasi akan memberi dorongan pada pembeli untuk membaca dulu dan sambil berfikir akan membelinya.

7. Pembungkus dapat menimbulkan harga diri bagi yang membawa.

Dengan adanya kemasan maka akan menguntungkan produsen dan konsumen sebagaimana hal di atas. Hal ini sangat penting untuk dipahami oleh mitra sehingga dengan adanya pelatihan pengemasan akan memberikan wawasan baru bagi mitra dan menjadi dasar pemikiran untuk mengembangkan usaha dengan melakukan pembaruan kemasan yang kreati dan inovatif karena dewasa ini fungsi kemasan juga sebagai pemasaran.

Selain pengemasan hal penting lain yang dapat menunjang keberhasilan usaha adalah pemasaran. Selama ini pemasaran yang dilakukan oleh mitra adalah pemasaran offline dengan cakupan yang sempit artinya produk samiler hanya dipasarkan di sekitar Desa Purwoasri saja, padahal produk ini memiliki potensi besar untuk dipasarkan secara lebih luas. Oleh karena itulah diadakan pelatihan pemasaran dengan fokus pemasaran online berbasis IT. Salah satu kunci keberhasilan dunia usaha adalah tersedianya pasar yang jelas bagi produk mereka. Sementara itu kelemahan mendasar yang dihadapi adalah dalam bidang pemasaran dengan orientasi pasar rendah, lemah dalam persaingan yang kompleks dan tajam serta tidak memadainya infrastruktur pemasaran. Menghadapi mekanisme pasar 
yang makin terbuka dan kompetitif, penguasaan pasar merupakan prasyarat untuk meningkatkan daya saing. Oleh karena itu, peran teknologi diperlukan dalam mendorong keberhasilan perusahaan untuk memperluas akses pasar melalui pemanfaatan teknologi informasi berbasis web yang dapat digunakan sebagai media komunikasi pemasaran modern. Salah satu gagasan pemberdayaan usaha di era teknologi informasi sekarang ini adalah melalui pembuatan media pemasaran berbasis web serta pemanfaatan social networking. Media pemasaran berbasis web ini diperuntukan bagi perusahaan dalam mempromosikan usahanya, jalur akses informasi produk, melakukan transaksi usaha, serta melakukan komunikasi bisnis lainnya secara global, dalam rangka memperluas jaringan usahanya, serta dipercaya memiliki efisiensi anggaran yang cukup hemat (Muttaqin, 2011).

Adanya media pemasaran modern yang berbasis IT sangat membantu dan memudahkan mitra dalam menjalankan promosi dengan biaya yang efisien serta dapat menjangkau pasar yang lebih luas. Selain itu dalam media pemasaran online produk dapat kita kemas dan dirancang sedemikian rupa gambarnya sehingga terlihat menarik. Konsumen akan tertarik dengan gambar-gambar yang diupload. Media pemasaran online yang aktif digunakan adalah whatsapp dan instagram. Hal ini karena whatsapp dan instagram adalah media sosial yang paling sering digunakan oleh masyarakat mulai dari kalangan muda hingga dewasa.

\section{KESIMPULAN}

Kesimpulan yang didapatkan dari kegiatan pengabdian ini adalah:

1. Adanya peningkatan pemahaman dan keterampilan mitra dalam mengemas produk serta memasarkannya.

2. Adanya peningkatan nilai jual produk karena pengemasan yang bagus dan menarik.

3. Terciptanya produk samiler dengan inovasi baru yaitu samiler rasa udang dan dapat meningkatkan nilai gizi produk.

\section{REFERENSI}

Cenadi, Christine Suharto. 2000, Peranan

Desain Kemasan dalam Dunia

Pemasaran, Nirmana, Vol 2, No. 2, 92103, : http://puslit.petra.ac.id/journals /design

Muttaqin, Zainal. 2011, Facebook Marketing Dalam Komunikasi Pemasaran Online, Teknologi, Vol 1, No. 2, 103-109, : http://puslit.petra.ac. $\mathrm{id} /$ journals/design

Syamsudin,dkk. 2015, Desain Kemasan Makanan KUB Sukarasa Di Desa Wisata Organik Sukorejo Sragen, Benefit Jurnal Managemen dan Bisnis, Vol 19, No. 2, 181-188, : http://puslit. petra.ac.id/journals/design

Wyatt, J. C, Spiegelhalter, D, 2008, Field Trials of Medical Decision-Aids: PotentialProblems and Solutions, Proceeding of 15th Symposium on ComputerApplications in Medical Care, Washington, May 3.

Yusoff, M, Rahman, S.,A., Mutalib, S., and Mohammed, A. , 2006, Diagnosing Application Development for Skin Disease Using Backpropagation Neural Network Technique, Journal of Information Technology, vol 18, hal 152-159. 